\title{
The Concept and Management of Non-traditional Security in Southeast Asia
}

\author{
Jörn Dosch*
}

\begin{abstract}
The structural changes of the post-Cold War era have resulted in new views on the definition and nature of security. According to this new approach, security comprises aspects of non-traditional or soft security, in addition to the established hard or military security. This article discusses the changing political discourse on security in Southeast Asia before turning to a case study that exemplifies the management (or lack of it) of non-traditional security (NTS). It is argued that policy-makers within ASEAN have put increasing emphasis on identifying and addressing NTS issues which affect or even may destabilize the region. This commitment to NTS, however, does not go beyond the declaratory or rhetorical level. Few measures have been implemented. Due to the organization's strict adherence to the principle of non-interference into the member states' domestic affairs the association lacks the institutional prerequisites to effectively and efficiently respond to the changing dynamics of regional security.
\end{abstract}

Keywords: ASEAN, Southeast Asia, Non-traditional Security

\section{Introduction}

$\mathrm{T}$ he structural changes of the post-Cold War era have resulted in new views on the definition and nature of security. In Southeast Asia as anywhere else in the world, in the early 1990s, economic development and military security became intertwined in a way never before seen. Among the most important contributions to this discourse is the concept of human security, which has emerged as the core of a new and broader understanding of security. According to this new approach, security comprises aspects of non-traditional or soft security, in addition to the established hard or military security. The economic crisis of 1997-98, transborder environmental problems such as the »haze « and avian flu, terrorism, but also the prevalence of hard security such as changing power relativities in the Asia-Pacific, the disputes in the South China Sea and tensions between member states due to unresolved border and territorial conflicts, to name only a few examples, have contributed to the rapid broadening of the security agenda in Southeast Asia. However, the coin called security has two sides which complement each other but - in analytical terms - have to be seen as discrete variables. These two dimensions are, first, the perception of the changing security dynamics and, second, the management of security-relevant policy areas. This distinction is particularly relevant with regards to Southeast Asia where the identification of newly emerging security issues does not necessarily imply the implementation of appropriate policy strategies do address these threats and challenges. This article will begin with an overview of the changing political discourse on security in Southeast Asia before turning to a case study that exemplifies the management (or lack of it) of non-traditional security (NTS). The study will delve into the Association of Southeast Asian Nation's (ASEAN) ${ }^{1}$ responses to the new security agendas in the regional context of Southeast Asia. I will argue that since the Asian crisis of 1997-1998 unmistakably demonstrated the importance of economic security

* Professor of Asia Pacific Studies, University of Leeds, United Kingdom.

1 ASEAN was founded in Bangkok in 1967 by Indonesia, Malaysia, the Philippines, Singapore and Thailand and has since been joined by Brunei (1984), Vietnam (1995), Laos and Myanmar (1997) and Cambodia (1999). ASEAN comprises all states of Southeast Asia except East Timor, which only achieved national independence in 2002 and might become a member at a later stage. for regional order and stability, policy-makers within ASEAN have put increasing emphasis on identifying and addressing non-traditional security issues which affect or even may destabilize the region. This commitment to NTS, however, does not normally go beyond the declaratory or rhetorical level. While an ever growing number of agreements on issues such as the fight against terrorism, the fostering of maritime security, the reduction of human trafficking and illegal migration or responses to environmental threats correctly identify the necessity for joint regional efforts in dealing with new security challenges, few measures have been implemented. Due to the organization's strict adherence to the principle of non-interference into the member states' domestic affairs and ASEAN's traditional approach to cooperation which is characterized by soft institutionalization, nonbinding and non-confrontational decision-making, and consensus building (the so-called ASEAN way), the association lacks the institutional prerequisites to effectively and efficiently respond to the changing dynamics of regional security.

\section{The changing dynamics of security in Southeast Asia}

What exactly is security and how does it come about? Security is not the product of any predictable rules, it depends on individual threat perceptions, it differs greatly according to an actor's status and position within the international system, and most important, it is subject to interpretation. Historically, security was understood in terms of threats to state sovereignty and territory. During the Cold War and particularly after the Vietnam War, it was generally thought that any further serious armed conflict in Southeast Asia would take place either as the result of conflicts between the great powers or their clients or due to unresolved territorial and border disputes, for example between Malaysia and the Philippines over the status of Sabah. While many territorial conflicts still remain unresolved, the overall security threat to the region has changed substantially since the late 1980s. At the same time, globalization has produced a simultaneous emergence of localization with more emphasis on local issues and revival of traditional local or intra-national conflicts, which had been suppressed 
by the ideological divide of the Cold War and nuclear deterrence. Such tensions inevitably impact regional stability.

Among the most important contributions to the post-Cold War discourse on security is the concept of human security, which to many presented not only a useful alternative to the traditional concept of security but also a welcome departure from the rather narrow debate on human rights that had emerged as one of the central soft security rallying points in international relations in the immediate aftermath of the Cold War (Sudarsono 1996, pp. 69-73). As fostered by the UN Development Programme (UNDP), »human security « usually means freedom from fear and want. The UNDP's 1994 Human Development Report stressed:

»The concept of security has for too long been interpreted narrowly: as security of territory from external aggression, or as protection of national interests in foreign policy or as global security from the threat of nuclear holocaust. It has been related to nation-states more than people. . . . Forgotten were the legitimate concerns of ordinary people who sought security in their daily lives. For many of them, security symbolized protection from the threat of disease, hunger, unemployment, crime, social conflict, political repression and environmental hazards.«(UNDP 1994, pp. 22-23).

While the UN deserves credit for promoting the concept of human security, the idea as such was not a new one in 1994. A few years earlier Barry Buzan (1991) already emphasized, »the security of human collectives is affected by factors in five major sectors: military, political, economic, societal and environmental and discussed in detail the notion of individual security« (p. 19). Security in a traditional sense can be understood as a »top-down « approach, which is associated with protection of the state from physical or ideological subversion. " Human security<, by contrast is a bottom up approach: what matters is the people and their well-being « (Evans 1999, p. 59). The idea of human security rapidly moved to occupy centre stage in discussions of foreign policy and made its way onto the agendas of the EU, the UN, the Group of Eight (G8), and eventually international organizations and also individual actors in the Asia Pacific. During the late 1990s, Japanese foreign minister and later prime minister Keizo Obuchi referred to the concept of human security in many of his speeches and defined it as »the keyword which encompasses the notion of arresting all the menaces that threaten the survival, of daily life and dignity of human beings « (quoted in Hoshino 1999, p. 43). Regional problems such as the haze crisis of 1997-1998, which was created by hazardous forest fires in Indonesia and resulted in diplomatic quarrels in relations between Indonesia, Singapore, and Malaysia as well as an estimated US\$ 9.3 billion in economic losses to the region, and particularly the Asian economic crisis, highlighted the need to look beyond the traditional notion of security.

While it can be argued that human-centric norms in Southeast Asia first emerged in 1993 when the World Conference on Human Rights forced ASEAN members to formulate a stance regarding human rights issues, the change of perspective on security became particularly visible at the fifth meeting of the ASEAN Regional Forum, held in Manila in July 1998. At this meeting the organization's foreign ministers discussed the economic crisis in great detail and arrived at the conclusion that poorly designed reforms could negatively affect less privileged sectors of society and »impact on the peace and security of the region « (Burke 2001, p. 218). Although critics have questioned the significance of addressing developmental agendas and problems of governance as security issues, and have stressed that human security or generally non-traditional security was simply too broad a concept to be a useful analytical tool, »it is precisely because of its broad definition and its stress on the well-being of humanity as a whole that the concept of human security has an important political appeal that can transcend national boundaries « (Anwar 2003, p. 541). According to Amitav Acharya (2001), human security and in a broader sense non-traditional security is »a distinctive notion, which goes well beyond all earlier attempts by Asian governments to redefine and broaden their own traditional understanding of security as protection of sovereignty and territory against military threats« (p. 459).

At least ten non-traditional security complexes in the Asia Pacific can be identified that have appeared on the radar screen of policymakers in the region and started to impact Southeast Asian security:

- Environmental deterioration and its deleterious effects on human health and trans-boundary pollution problems.

- Growing pressures on natural resources due to expanding market demand, particularly with respect to forestry and fishery resources.

- Developmental policies.

- The broad field of democracy and human rights.

- Legal and illegal migration and resulting ethnic tensions.

- Increasingly violent criminal acts, prostitution, human trafficking (people smuggling), and drug trafficking.

- Increasing gaps in wealth and income within and between neighbouring regions, in part as a result of international and transnational economic exchanges.

- Mismanagement of national economies and their vulnerability to the intensifying forces of globalization, resulting in major economic and social dislocations among the local populations.

- Separatism, insurgency, and terrorism.

- Maritime piracy.

As anywhere in the world, events since 11 September 2001 probably have had the most dramatic impact on security perceptions in Southeast Asia. The war on terror's perceived spill-over to the region led to the view that the manifold and devastating impacts of terrorism are among the most decisive non-traditional security challenges. Initially after 11 September the vast majority of Southeast Asian politicians and academics expressed deep concern that the United States was overreacting in Southeast Asia by putting pressure on the predominantly moderate Muslim societies in the region and declaring Southeast Asia to be the »second front « in the war on terrorism. While US officials mostly resisted such a characterization, there is no doubt that Southeast Asia quickly moved into a central position on Washington's geo-strategic antiterrorism agenda in the wake of 11 September. The mainstream 
perception within the region of terrorism as a low-level threat substantially changed following the terrorist attacks in Bali, Indonesia, on 12 October 2002, during which members of the Jemaah Islamiya group bombed two nightclubs in the tourist district of Kuta and killed more than 200 people. To some the escalation of terrorist violence did not come as a surprise. In February 2002, for example, Lee Kuan Yew warned that the people of Southeast Asia were exposed to a continuing security risk because the ringleaders of extremist cells roamed freely in Indonesia (Associated Press, 17 February 2002). The threat of terrorism in Southeast Asia has also had direct implications for US economic interests. Since 11 September 2001 the United States has viewed extremist movements in Indonesia, Malaysia, the Philippines, and Thailand as a potential hazard to world commerce flowing through the region's important sea-lanes of communication. »The nightmare for the United States is that a supertanker will be hijacked and driven into Singapore port, or some larger port, or sunk in the Malacca Strait by use of weapons from afar, thus seriously disrupting or detouring the flow of oil to East Asia and potentially blocking US naval mobility and flexibility as well « (Young and Valencia 2003, pp. 276-277). Furthermore, according to the Washington, D.C. based Maritime Intelligence Group, Al-Qaida is believed to operate fifteen to twenty-five vessels transporting weapons and personnel in the Mediterranean Sea and the Indian and Atlantic Oceans. This has led to concerns in US defence circles that weapons of mass destruction could be shipped through the Malacca Strait (Tucker-Jones 2004). Many Southeast Asian observers, however, believe that the US scenario was greatly exaggerated and served the main purpose of creating support for an American naval presence in and around the Straits of Malacca, something that is strongly favoured by Singapore but rejected by Malaysia. ${ }^{2}$ It should also be noted that not all agree with the inclusion of terrorism on the NTS agenda. According to the deputy director of the Southeast Asia Regional Centre for Counter-Terrorism (SEARCCT) »terrorism is very much related to traditional security issues and dealt with as part of defence policy «. ${ }^{3}$ But this is more a problem of definition and not substance. Ultimately - as the »Copenhagen School« has taught us - any issue can be constructed as an »existential threat « as the result of a multi-step process for which Buzan et al. (1998) coined the term securitization.

To be sure, the emergence of a broader security culture that increasingly includes non-traditional elements does not mean the disappearance of »hard « security issues - or what Sheldon Simon calls »classical concerns « $(2001$, p. 3) - such as crisis on the Korean Peninsula, the conflict-ridden Sino-Japanese relations, or the territorial disputes in the South China Sea and particularly over the Spratly islands. Neither does the discourse on NTS imply any declining or even vanishing importance of hard security thinking among the region's armed forces. As a senior official of the Malaysian Ministry of Defence put it, "NTS is a major concern, but we would not compromise on traditional security capabilities. « ${ }^{4}$ To a high-ranking

2 Author interviews with senior government officials and scholars in Singapore and Malaysia in 2005 and 2006.

3 Author interview with the deputy director Lt Col Tuan Roslan Tuan Ismail in Kuala Lumpur, 25 October 2005.

4 Author interview in Kuala Lumpur, 25 October 2005. officer of Singapore's armed forces, the relative reluctance of the Southeast Asian defence establishments to change their perception of security is mainly related to the »inflexibility of the military structure which was put into place to respond to military threats and nothing else«. However, the views on NTS among the armed forces of Asia vary. While there is a tendency among the Malaysian military to cling to the view that "non-traditional security is not our job «, there seems to be a greater openness among the armed forces of Indonesia and - to give two examples from South Asia - India and Pakistan to deal with new non-military security challenges. According to an Australian officer, NTS is first and foremost a political issue but if politicians labelled an issue as a threat to security the military would get inevitably involved, for example with regards to illegal migration in Australia's case. ${ }^{5}$

\section{ASEAN's approach to the Management of Non-traditional Security}

Given the prevalence of hard security conflicts such as the South China Sea dispute, William Tow questions »the likelihood of the ASEAN elite to shift their focus from traditional security postulates (state-centric territorial, diplomatic and territorial concerns) to a broader set of referents incorporating sunstructured threats (those emanating from beyond boundaries or state structures) of a non-military and personal nature (2001, p. 268). Anwar (2003, pp. 536-537) believes that due to a persistent state-centred and community-oriented approach in Southeast Asian politics, combined with predominantly inward-looking security preoccupation of many Asian countries, human security and indeed any extended approach to security are of secondary importance. At the same time, this assessment only partly holds true. While most national security doctrines in Southeast Asia still subscribe to a traditional realist approach and perspective, there can be little doubt that the vast majority of governments in the region have long de facto acknowledged the relevance of a multidimensional approach to security at least implicitly. Although a consensus on the ultimate relevance of NTS as both a political and military issue has yet to emerge, it seems to be safe to conclude that the ASEAN governments today perceive traditional and nontraditional security as the two sides of the same coin, although at varied degrees of consciousness.

Singapore is a case in point for a national security culture comprising military, economic, and social factors. The citystate is extremely and to a significantly higher degree than most of its regional neighbours concerned about its position and status within the international system. The perception of vulnerability is the main structure of Singapore's foreign and security outlook. »That vulnerability is a function of a minuscule scale, a predominantly ethnic-Chinese identity associated with a traditional entrepôt role and also a location wedged between the sea and airspace of two larger neighbours [In-

\footnotetext{
5 These views were gathered during a roundtable discussion, chaired by this author, on 25 October 2005 at the Malaysian Armed Forces Defence College with senior officers from the armed forces of Malaysia, Singapore, Indonesia, Pakistan, Australia and the UK and a further seminar with members of the Malaysian military at the same place on 17 April 2006.
} 
donesia and Malaysia] with which Singapore has never been politically at ease« (Leifer 2000b, p. 1). This »deep security complex « also drives Singapore's foreign economic policy. The feeling of insecurity has forced Singapore to pursue aggressively economic advancement to protect itself, not simply to improve the lives of its people. Singapore's recent initiatives to establish bilateral free trade agreements (FTAs) on a global scale have been very successful. By mid-2005, Singapore had concluded eight FTAs while ten more were under negotiation. ${ }^{6}$ This drive to FTAs is not just economic, by any means. From the government's point of view, the agreements enhance the city-state's political recognition and profile and serve a direct security purpose, for example as a means of keeping the United States engaged in the region. Singapore views the US presence as vital to the security and stability of Southeast Asia (Rajan et al. 2001, p. 76). A further striking example for the embeddedness of non-traditional in traditional security was Singapore's response to the tsunami catastrophe of 26 December 2004. The city state was the first ASEAN member to respond to the disaster by offering substantial help to Indonesia, the country most affected by the tsunami and, incidentally, the state Singapore has been most wary of during its history as an independent nation. As K.S. Nathan puts it, »This was a message that could not be missed: the smallest ASEAN state helping the biggest one. Singapore enhanced its security by providing human security assistance to Indonesia. « ${ }^{7}$

The security-economic nexus is also present in Vietnam's policies. In December 1986, Vietnam's foreign policy took a new course when the sixth National Congress of the Vietnamese Communist Party adopted a strategy of doi moi, or renovation. Although the new approach was primarily directed toward reform and liberalization of the national economy, it had decisive implications for Vietnam's foreign policy and security outlook. The political elite concluded that the international isolation of Vietnam following its occupation of Cambodia in 1979 had contributed significantly to the country's deep socioeconomic crisis (Dosch and Ta 2004). In sum, doi moi was driven by the realization that the main security challenges to Vietnam were not primarily the result of aggressive behaviour on the part of foreign powers, but stemmed from the poor state of the economy with all its consequences, such as poverty and economic degradation (Tan and Boutin 2001, p. 3).

In Thailand, the political and economic changes of the early 1990s have distorted the dominant role of the military elite in defining Thai concepts of national security. Among the most visible results has been the broadening of traditional security conceptions to include economic development, equality, liberty, and justice, with a special focus on political reform, decentralization of the bureaucracy, human rights, and environmental issues (Panitan 1998, p. 429).

Indonesia's traditional doctrine of national resilience (Ketanahan Nasional) is perhaps the oldest explicit concept of a flexible and open approach to security, which was later also adopted at the regional level as the »rhetorical centerpiece «

\footnotetext{
6 The eight concluded FTAs were with Australia, the European Free Trade Association, India, Japan, Jordan, New Zealand, South Korea, and the United States. The ten FTAs under negotiation are with Bahrain, Canada, Egypt, Kuwait, Mexico, Panama, Peru, Qatar, Sri Lanka, and the United Arab Emirates. 7 Author interview in Singapore, 10 April 2006.
}

of ASEAN's approach to regional security (Emmerson 2001, p. 95). The doctrine is based on the assumption that »comprehensive security, involving >ideology, politics, economy, sociocultural and military< strength . . . combined with a cooperative approach at the seconomic, social and cultural levels, would . . . lead to regional resilience« (Ferguson 2001, p. 124125), with this being the precondition for a stable and secure international environment.

Southeast Asia's changing discourse on security is most visible at the regional level and particularly with regard to initiatives to counter trans-national crimes and terrorism. A long-standing taboo was broken when ASEAN adopted a road map for a region-wide human rights commission in May 2003. Despite its non-binding nature (in customary ASEAN fashion), the road map marks the crucial first initiative to address the issue of human rights in intraregional relations. Furthermore, ASEAN has established the Southeast Asia Regional Centre for Counter-terrorism, in Kuala Lumpur, which organizes training programs, workshops, and seminars to help the region implement counter-terrorism efforts. Having already agreed on a plan of action to combat transnational crime, ASEAN members are currently working on a region-wide treaty on antiterrorism legal procedures. In a drive against terrorism, drug trafficking, money laundering, and other cross-border crimes, the proposed agreement aims to reduce legal impediments to cooperation in tackling such problems. Among the most successful examples of emerging cooperation on NTS issues is the coordinated fight against piracy (also referred to as sea robbery) and, in general terms, joint approaches towards the maintenance of maritime security in the Straits of Malacca. At the centre of the so-called »eye in the sky« initiative is the joint aerial surveillance of potentially security-threatening activities in the Straits involving all three riparian states Indonesia, Singapore and Malaysia. »In practical terms this means that personnel from these three countries are in the same aircraft monitoring the security of the Straits «, as a senior official of the Malaysian Ministry of Defence explains. ${ }^{8}$ In addition to intra-ASEAN activities, ASEAN and China have identified priorities of cooperation against transnational crime, namely terrorism, sea piracy, human and drug trafficking, and international economic crimes.

At the same time, we should not blind ourselves to the fact that all currently existing institutional agreements within the area of NTS are of a non-binding nature. »Eye in the sky « and other initiatives such as coast guarding, anti-terrorism measures and approaches to the management of environmental security, such as the haze problem, are held up by sovereignty issues (ASEAN members usually avoid the word »joint « when referring to cross-border cooperation and use the term »coordinated activities « instead as the first might hint a supranational approach while the latter describes - less suspiciously - inter-governmental cooperation), controversies over the establishment of enforcement agencies and generally a lack of policy implementation. According to a Malaysian government official, »at an operational level we [in ASEAN] are still not clear as to how we can effectively and efficiently address nontraditional security challenges in a coordinated fashion. ${ }^{9}$

8 Author Interview in Kuala Lumpur, 25 October 2005.

9 Author Interview in Kuala Lumpur, 17 April 2006. 
Whether or not multilateral cooperation on NTS issues is efficient and successful greatly depends on the goodwill of the actors involved to agree on collective norms and procedures in response to the existing security challenges. This is particularly the case with regard to the broad issue of non-state violence. If one believes the enumeration efforts of the RAND Corporation, terror in Southeast Asia is not a recent phenomenon but has increased significantly in importance in the post-Cold War era. The RAND terrorism chronology counts 90 international terrorist attacks in the region of Southeast Asia and Oceania during the eighteen-year period 1968-1985. In the following eighteen year period (1986-2002), international terrorist attacks in the region more than doubled, to 194 (Swanström and Björnehed 2004, p. 329). However, neither with regard to violence in Mindanao, nor Aceh nor Southern Thailand nor any other conflict-ridden place in Southeast Asia ${ }^{10}$ has ASEAN ever played any kind of a role. This seems to be surprising at first glance, given that the organization has embarked on various activities to deal with the pressing issues of local hotspots of violence. For example, the fourth ASEAN Chiefs of Army Multilateral Meeting (ACAMM), which took place in 2003 in Kuala Lumpur, called for solidarity among the armies of member countries in fighting terrorism in the interests of the region. Nine ASEAN countries participated. Although the army chiefs agreed that the ACAMM should work toward forging stronger ties among ASEAN armies, such as networking among ASEAN military intelligence and exchanging methods of how to combat terrorists, no specific actions were agreed upon. ${ }^{11}$ This approach is typical for ASEAN, as it reflects the organization's core norms and principles: soft institutionalization, nonbinding and non-confrontational decision-making, and consensus building. ASEAN's response to the perceived threat of terrorism in general and radical Islamic groups in particular provides a good illustration of this so-called ASEAN way and its ineffectiveness in addressing NTS challenges. The 2001 "ASEAN Declaration on Joint Action to Counter Terrorism « commits the member states »to counter, prevent and suppress all forms of terrorist acts in accordance with the Charter of the United Nations and other international law, especially taking into account the importance of all relevant UN resolutions, « without prescribing a specific institutionalized pattern for dealing with the problem. Although ASEAN has established a regional framework for fighting trans-national crime and adopted an action plan outlining a regional strategy to prevent, control, and neutralize trans-national crime, the organization's overall response to the threat and realities of terrorism mirrors its traditional policy for not committing its members to any specific responsibilities. The action plan is based on the principle of voluntary contribution. The cautious approach of some ASEAN states to anti-terror cooperation is also prominently reflected by the »US-ASEAN Joint Declaration for Cooperation to Combat International Terrorism «. The document includes a paragraph that the US side was initially unwilling to accept: »Recognizing the principles of sovereign equality, territorial integrity and non-intervention in the domestic affairs of other states. « The paragraph was added

10 The dynamics of these conflicts - including the question as to whether or not »terrorists « are at work - cannot be discussed here due to space constraints. See

Dosch 2007, chapter 3, for a detailed analysis of violence in Southeast Asia.

$11 »$ Armies Against Terror, « Asian Defence and Diplomacy (October 2003), pp. 47-49. to the declaration at the request of Indonesia and Vietnam, which feared that such an anti-terror accord with the United States could lead to the basing of US troops in Southeast Asia. In sum, both documents reflect the lowest common denominator and do not create any binding obligations for ASEAN members, because of a missing consensus on an exact definition of terrorism and, equally important, because the issue touches on the sensitive field of national sovereignty.

While ASEAN has never failed to address the most pressing NTS issues in inter-member relations and vis-à-vis the external environment on a rhetorical level, such as the implications of the Asian economic crisis, the haze crisis, terrorism, or illegal migration, not a single initiative has ever been fully implemented. Avian influenza is the most recent example. On the one hand, there is general agreement among ASEAN members that bird flu can only be tackled through close cross-border cooperation; member states signed a regional action plan that is supposed to define the policy framework to contain the disease; and they set up a regional surveillance and alert network. On the other hand, even in the diplomatic language of the group's top representative, Secretary-General Ong Keng Yong, serious concerns about the effectiveness of the scheme came to the fore. According to Ong, »it will still take some time to perfect the system « and »there are still pockets of inadequacy, especially in terms of getting bureaucracy in all different departments mobilized.« Although Ong expressed confidence that ASEAN would ultimately be able to overcome these difficulties, he admitted that some member nations of ASEAN lacked transparency in the information they released about bird flu, and that outbreaks in remote areas were not reported fast enough. ${ }^{12}$ Most crucially, ASEAN lacks funds to compensate farmers whose poultry flocks are killed as a precaution. As a result, many farmers in affected areas are reluctant to report outbreaks and even hide sick chickens, because their livelihood depends on them.

Few observers would challenge the view that beyond the political rhetoric and well-sounding declarations and agreements which all fall into the category of nonbinding soft law ASEAN lacks substance and, more specifically, both the political will and the institutional setting to translate perceptions into strategies and ultimately implemented policies. In view of the clear limits to the management of NTS within the ASEAN framework, a growing number of member states perceive ASEAN as a golden cage that - unlike during Cold War days - does not necessarily serve their policy interests to the fullest possible extent. Singapore, Thailand and to a slightly lesser degree Malaysia and Indonesia do not necessarily feel constraint anymore by ASEAN as far as the conduct of their foreign affairs is concerned and have emancipated their foreign policies: for example Thailand on the issue of relations with Myanmar and Singapore with regards to bilateral trade agreements. There is a growing perception among Singapore's foreign policy makers that no matter how much ASEAN develops from an institutional point of view »it will not be enough for Singapore $«{ }^{13}$

12 Address to an Asia Society luncheon, Hong Kong, 1 November 2005, quoted in »ASEAN Sees Close Cooperation on Bird Flu, Disaster Relief, Crime, « Voice of America, 1 November 2005.

13 Author interview with a senior official in the Ministry of Foreign Affairs in Singapore, 11 April 2006. 


\section{Conclusion}

A rapidly growing number of non-traditional security complexes in the Asia-Pacific has got attention of policy makers and started to impact on regional security, including environmental deterioration; growing pressures on natural resources; developmental policies; the broad field of democracy and human rights; legal and illegal migration and resulting ethnic tensions; increasingly violent criminal acts, prostitution, human trafficking (people smuggling) drug trafficking and piracy; increasing gaps in wealth and income within and between neighbouring regions in part as a result of international and transnational economic exchanges; mismanagement of national economies and their vulnerability to the intensifying forces of globalization; and separatism, insurgencies and terrorism. ASEAN has embarked on various regional initiatives to respond to these non-traditional security challenges. While there is no shortage of a declaratory commitment to conflict resolution, ASEAN's contribution to the management of new security challenges has been very limited. For example, as an organization, ASEAN has not contributed to the peace-building processes in Aceh, Mindanao, and southern Thailand. And although new regional initiatives, such as the South East Asian Centre for Counter-terrorism (SEARCCT), look good on paper, as they seem to indicate ASEAN's ability to coordinate national approaches in the struggle against NTS challenges, the real impact on the management of regional affairs is low. A senior officer at the SEARCCT admits that »this is a centre for training not intelligence sharing. The latter would be difficult to achieve because the national intelligence agencies of the ASEAN states sometimes refuse to share information. ${ }^{14}$ There can be no doubt as to ASEAN's and its member governments' awareness of the nexus of global, regional, and national/local developments and structures that are particularly relevant to security. At the same time, due to the organization's strict adherence to the informal consultation, non-binding decision-making, and noninterference into members' internal affairs, ASEAN's capacities and capabilities of responding to regional challenges are very limited. Although ASEAN has established a regional framework for fighting transnational crime and adopted an action plan outlining a regional strategy to prevent, control, and neutralize transnational crime, the organization's overall response to the threat and realities of terrorism and other major NTS challenges clearly mirrors its traditional policy of not committing its members to any specific responsibilities.

\section{References}

Acharya, Amitav (2001). "Human Security: East versus West«. International Journal, vol. 3, pp. 442-460.

Anwar, Dewi Fortuna (2003). Human Security: An Intractable Problem in Asia. In Muthiah Alagappa, ed. Asian Security Order. Instrumental and Normative Features. Stanford: Stanford University Press, pp. 536-570.

Buzan, Barry (1991). People, States \& Fear. An Agenda for International Security Studies, $2^{\text {nd }}$ edition Boulder/Colorado: Lynne Rienner Publishers, 1991, p. 19.

14 Author interview in Kuala Lumpur, 25 October 2005.
Buzan, Barry; Ole Waever and Jaap de Wilde, eds. (1998). Security. A New Framework for Analysis. Boulder/Colorado: Lynne Rienner Publishers.

Collins, Allan (2003). Security and Southeast Asia. Domestic, Regional, and Global Issues. Boulder and London: Lynne Rienner Publishers.

Dosch, Jörn (2006). The Changing Dynamics of Southeast Asian Politics. Boulder and London: Lynne Rienner Publishers.

Dosch, Jörn, and Ta Minh Tuan (2004). »Recent Changes in Vietnam's Foreign Policy: Implications for Vietnam-ASEAN Relations. «In Duncan McCargo, ed., Rethinking Vietnam. London: RoutledgeCurzon, pp. 197-213.

Emmerson, Donald K. (2001). „Golilocks's Problem: Rethinking Security and Sovereignty in Asia."In Sheldon W. Simon, ed., The Many Faces of Asian Security. Lanham: Rowman and Littlefield, pp. 89-114.

Evans, Gareth (1999). »Human Security and Society«. The AsiaAustralia Papers, no. 2, September, pp. 59-63.

Ferguson, James R. (2001). »New Forms of Southeast Asian Governance: From >Codes of Conduct to >Greater East Asia.« «In Andrew T. H. Tan and J. D. Kenneth Boutin, eds., Non-Traditional Security Issues in Southeast Asia. Singapore: Select Publishing, pp. 122-165.

Leifer, Michael (2000). Singapore's Foreign Policy: Coping with Vulnerability. London: Routledge.

Panitan Wattanayagorn (1998). »Thailand: The Elite's Shifting Conceptions of Security. "In Muthiah Alagappa, ed., Asian Security Practice: Material and Ideational Influences. Stanford: Stanford University Press, pp. 417-444.

Rajan, Ramkishen S., et al. (2001). Singapore and Free Trade Agreements: Economic Relations with Japan and the United States. Singapore: ISEAS.

Simon, Sheldon W. (2001). »Introduction «. In Sheldon W. Simon, ed. The Many Faces of Asian Security. Lanham et al.: Rowman \& Littlefield, pp. 1-14.

Sudarsono, Juwono (1996). Surviving Globalization. Indonesia and the World. Jakarta: Jakarta Post Books.

Swanström, Niklas, and Emma Björnehed (2004). „Conflict Resolution of Terrorist Conflicts in Southeast Asia.« Terrorism and Political Violence 16:2, pp. 328-349.

Tan, Andrew T. H., and J. D. Kenneth Boutin (2001). Introduction to Andrew T. H. Tan and J. D. Kenneth Boutin, eds., NonTraditional Security Issues in Southeast Asia. Singapore: Select Publishing.

Tow, William T. (2001). »Alternative Security Models: Implications for ASEAN «. In Andrew T.H. Tan and J.D. Kenneth Boutin, eds. Non-Traditional Security Issues in Southeast Asia. Singapore: Select Publishing, pp. 257-287.

Tucker-Jones, Anthony (2004). »Web Special: War on Terror Update."Warship Magazine. http://www.warshipsifr.com/ pages/terrorism_special12.html.

UNDP (1994). UN Human Development Report. New York: Oxford University Press.

Young, Adam and Mark Valencia (2003). „Conflation of Piracy and Terrorism in Southeast Asia: Rectitude and Utility«. Contemporary Southeast Asia, 25:2, pp. 269-283. 